\title{
EARTH SYSTEM PROCESSES OF THE WALLACEA AND THEIR IMPLICATIONS TO THE INDONESIAN THROUGHFLOW AND BIOGEOGRAPHY
}

\author{
Jan Sopaheluwakan \\ Research Centre for Geotechnology \\ Indonesian Institute of Sciences, Jln. Cisitu 21/154D, Bandung 40135, Indonesia \\ E-mail: jan.sopaheluwakan@lipi.go.id
}

Received: December 2010

Accepted: January 2011

\begin{abstract}
The Wallacea with the total land area of $347,000 \mathrm{~km}$ designates a biogeographical group of Eastern Indonesian islands separated by deep water straits from the Asian and Australian continental shelves, and occupies a region with the world's most complex geological evolution and the accompanying extreme endemism. It also encloses remnants of emerged and submerged lands as well as dispersed and accreted island arcs and fragments of the continents resulting from a relatively continuous Cenozoic convergence of the Indo-Australian, Eurasia and Pacific-Philippine Sea plates.This paper discusses the Cenozoic spatial and temporal evolution of terranes in the region and explores how the Earth System Processes have eventually shaped up the Indonesian Throughflow and highlights the biogeographically unique and rich Wallacea. It will be demonstrated that the Wallace's line may have inherited an evolved multi-origin Early Cenozoic deep water barrier and the present Wallacea has been the resultant of significant Neogene convergent tectonics and significant modification by glacially-related sea level and climatic changes during the Quaternary. The gradual and systematic changes of the respective ocean regimes, the corresponding oceanometeorologic evolution, the emergence and disappearance of islands and land bridges, the dispersal and docking of some terranes have all resulted in the present configuration of the areas of endemism within the Wallacea. These changes correspond with the Neogene closure of the Indonesian Seaways, a narrow passage formed by the collision of the three major plates and the vanished pre-Cenozoic Tethyan ocean formed by the otherwise connected Indian and Pacific Oceans.
\end{abstract}

Keywords: Earth System Science, Wallacea, Indonesian Throughflow, Neogene Closure

\section{INTRODUCTION}

Wallacea has been used to a biogeographical designation for a group of Indonesian islands separated by deep water straits from the Asian and Australian continental shelves. The Islands of Wallacea lie between Sundaland (the Malay Peninsula, Sumatra, Borneo, Java, and Bali) to the west, and Near Oceania including Australia and New Guinea to the south and east. The total land area of Wallacea is $347,000 \mathrm{~km}^{2}$ (Figure 1). The diversity of the terrestrial biota results from the meeting and mixing of the floras and faunas from two major zoogeographic regions, which were physically separated and subsequently became connected, making the opportunities for speciation on the islands of the Indo-Malay region (Benzie, 1998).

The region, which is formed by four major Earth System processes, endows the world's richest geodiversity, as well as the ocean, terrestrial and marine biodiversities and their endowing hotspots. The first three Earth System processes consist of: (i) the rapid plate movements during the Cenozoic and the accompanying geological changes which have driven changes in the distribution of land and sea (Hall, 1998; 2001; Sopaheluwakan, 1990, Nishimura and Suparka, 1997; Linthout et al., 1997); (ii) the concomitant oceanographic changes leading to the revolutionary Neogene closure of Indonesian Seaways (Kennet et al., 1985; Cane 


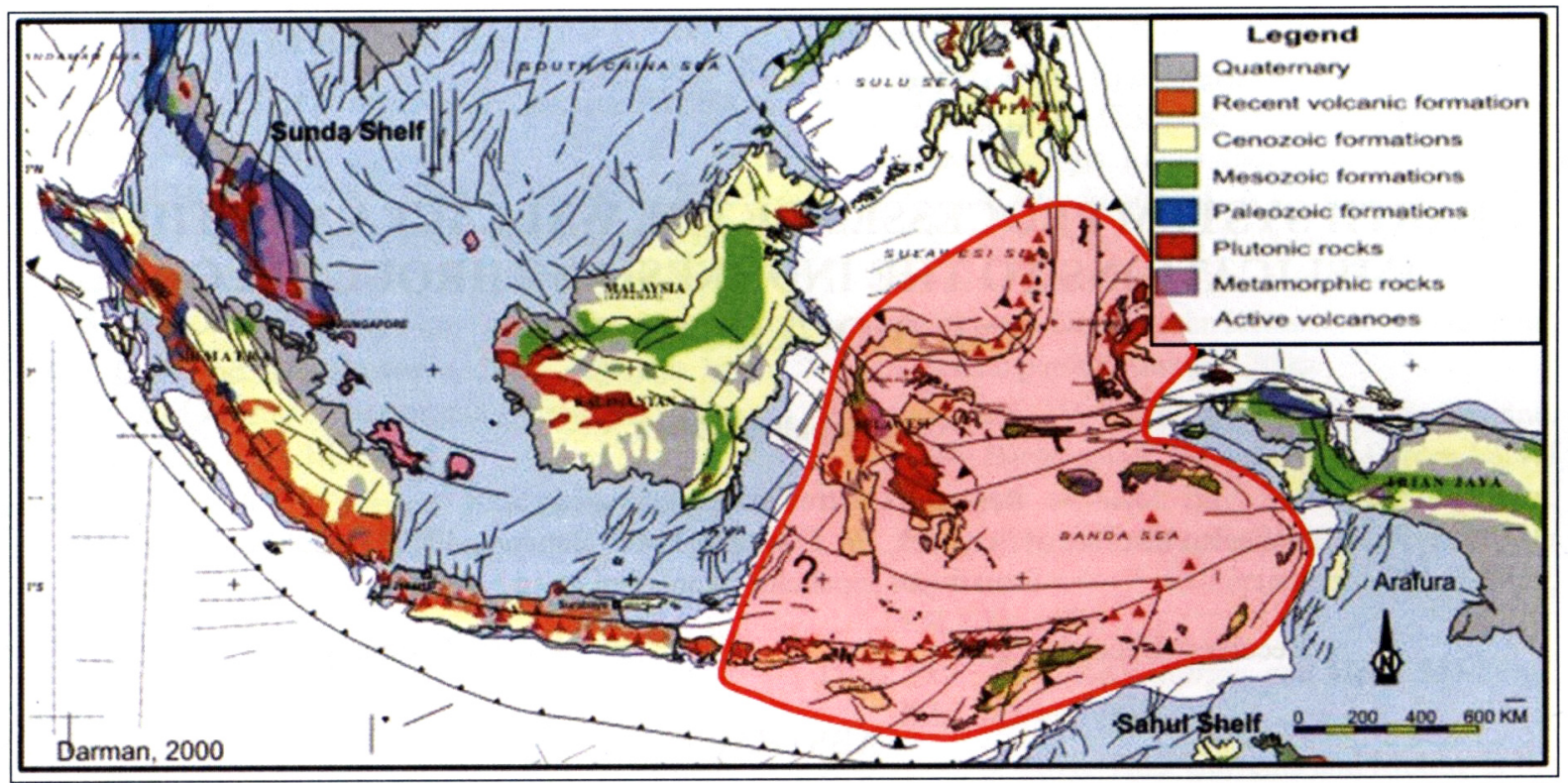

Figure 1. Regional geology of Indonesia and the distribution of Wallacea (shown in red), depicting the extent of the Sunda and Sahul shelves and the intervening Wallacea which exactly occupies the Cenozoic collision zone (regional geology after Darman, 2000).

and Molnar, 2001); and (iii) the biogeographic evolution (e.g. Moos and Wilson, 1998) which ends up with the present biodiversity of the Wallacea. The climatic evolution which is the fourth important processes, however, will also be shortly highlighted here. The prime mover, i.e. the geological changes, has thus clearly influenced other factors such as ocean currents and local climatic patterns, which in turn are likely to have influenced the biogeographic patterns. In addition, the animals and plants themselves have changed as a result of evolutionary processes.

This paper attempts to view the Wallacea region from the Earth System Science which seeks to integrate various fields of academic study to understand the Wallacea as a system and looks at interaction between the atmoshpere, hydrosphere, lithosphere, biosphere and heliosphere within the region. This will likely to be of value to understanding Wallacea's complex geology, physiography, biogeography, climatic and biotic evolution rather than as the single explanation of the patterns observed at the present day. Despite the fact of our less knowledge on the marine organism, this paper will also highlight the link between the tectonics of the Wallacea window and the paleoceanographic evolution within the Wallacea which was formed as results of the Cenozoic separation of the otherwise unified
Pacific and Indian Oceans. Likewise, the interplay between the climatic aspects of the Wallacea and the Indonesian Throughflow will also be very briefly illuminated here and there.

\section{TECTONIC EVOLUTION OF THE WALLACEA AND THE CLOSURE OF INDONESIAN SEAWAYS}

The "Wallacea window" has captured quite a complex tectonic evolution involving drifting, rotation, fragmentation, translation, dispersal, docking and amalgamation of continental masses, oceanic crusts, and island arcs. The tectonic evolution of the Wallacea has always been a subject of high interest and controversy since the pre-war time when the fixistic undation theory dominated and explained the mountain building processes through vertical movement and sliding tectonics (e.g. Umbgrove, 1942; van Bemmelen, 1949). They argued that the mechanism behind orogeny was in the mantle, in that due to geochemical differentiation slight differences in its density would lead to vertical flow in the mantle, resulting in orogeny.

With the advent of mobilistic plate tectonic theory in the 1970s, which basically explains that the earth lithosphere is divided into several large scale moving plates, converging and diverging 
each other. The vertical and horizontal movements of lithospheric plates in times and space were used to figure out and explain the paleogeographic setting and evolution of any particular region, including the Wallacea. Plate tectonics have found the Wallacea to be the prolific and foremost ground to explain, justify and elucidate how this theory works and its implication to the paleogeographic evolution, the distribution of land masses and seas and their migrating paths in time and space, the paleoceanographic evolution and even paleoclimatic and paleoenvironmental setting of the region (see e.g. Hall, 1998; 2001; Kennet et al., 1985; Nishimura and Suparka, 1997).

In the post-plate tectonic era (see e.g. Sopaheluwakan, 2007), scientists have comprehended a new paradigm dubbed as the whole Earth tectonics, which prime mover of all the changes has been the deep mantle plume tectonics (Maruyama, 1994; Maruyama et al., 1994). This theory stipulates that the subducted slabs in the western Pacific are stagnant at the $670 \mathrm{~km}$ discontinuity because of the endothermic phase transition and eventually collapse to form a cold mantle downwelling to the core mantle boundary (CMB). It also explains that two large-scale mantle upwellings are present in the lower mantle under the south Pacific and Africa (hot superplume). The whole-mantle scale convection controlled by the large-scale flow is called plume tectonics and should play a major role in the Earth's dynamics. Ancient activity of the South Pacific Superplume dated back to $600 \mathrm{Ma}$ as they were documented by analyzing greenstones which have been formed by the Pacific Superplume, migrated to circum-Pacific subduction zones and accreted into the subduction zone complex. The remnants of this Pacific Superplumes are found in the Cenozoic collision zones of the Wallacea islands and the adjacent areas like the East Arm of Sulawesi (Villeneuve et al., 2002; Parkinson, 1998), Java, Sulawesi and Kalimantan (Parkinson, 1998; Parkinson et al., 1998), Timor-Tanimbar belt (Helmers et al., 1989; Sopaheluwakan, 1990; Kaneko et al., 2007; Kadarusman et al., 2010), Seram (Linthout et al., 1997), Halmahera (Ballantyne et al., 1990) and northern Papua (Lus et al., 2004). These papers have earlierly presented different mechanisms of the emplacement of the Pacific (Tethyan) mantle materials onto the Asian and Australian continental margin. The slab-mantle reconstruction of the three-plate collisional Banda Sea area has been presented later by Spakman and Hall (2010).

The tectonic evolution of Eastern Indonesia, namely the within Wallacea, has been used quite widely to reconstruct the paleogeographic configuration and evolution of land masses and the intervening oceans. With the advent of plate tectonics, numerous attempts have been brought forward through different approach since the late 1970s (e.g. Katili, 1977) and accumulated by the systematic and computer based visual reconstruction for every 1 million year by Hall (2001; 2002), showing the pattern of land and sea configuration in the Wallacea window since the last $50 \mathrm{Ma}$. Some controversies with Hall's (2001, 2002) reconstruction arose, however, when dealing with the evolution of the critical boundaries of the Wallacea, namely the origin the Makassar Strait (see Figure 3), and the emergence of Timor, Buru and Seram (Figure 4) (Sopaheluwakan, 1990; 2000; Linthout et al., 1997). The Makassar Strait, where the Wallace Line was drawn, was regarded to have formed through an incomplete rifting due to the rise of enriched mantle materials (see Figure 3, Sopaheluwakan, 2000).

The overall evolution through dispersal and docking of the land masses, the closure of the Indonesian Seaways by continuous narrowing of the intervening oceans, and the pathways of the proto Indonesian Throughflows (ITF) are illustrated in Figure 4 (Sopaheluwakan, 2000). The opening of the strait was from the south moving to the north during the Eocene-Miocene times, driven by the uprise of enriched mantle along with the outboard younging of subduction zones eastward. The northward opening of the Makassar Strait slowed down during the Oligocene with the East Arm ophiolites emplacement and ceased as the Banggai-Sula microcontinent docked onto the East Arm in the Miocene. Furthermore, the dynamic interplay between the emergence, submergence, dispersal, translation and rotation of the inner and outer islands of the Banda Arc eventually determined the current pattern of ITF in the Banda Sea. The blockage by Lesser Sunda and Banda Arc and emergence of Timor, rapid exhumation of Timor-Tanimbar, and the rotation of the Buru-Seram were all responsible with the 
bouncing of the ITF by the Lesser Sunda Islands, and the clockwise turn around of the ITF in the Banda Sea which then flows on to the Ombai Strait and the Timor Passage.

In Timor-Tanimbar stretch, Quaternary uplift, marked by elevation of recent reefs, was estimated to be about $1260 \mathrm{~m}$ in Timor in the west and decreased toward Tanimbar in the east was considered to be the major cause of the blockage of the ITF in the eastern part of the Lesser Sunda Islands. Radiometric ages for the high $\mathrm{P} / \mathrm{T}$ metamorphic rocks suggest that the exhumation of the high $\mathrm{P} / \mathrm{T}$ metamorphic belt started in western Timor in Late Miocene time and migrated toward the east (Kaneko et al., 2007). Thus, the tectonic evolution of this region is diachronous and youngs to the east. Kaneko et al. (2007) conclude that the deep-seated high $\mathrm{P} / \mathrm{T}$ metamorphic belt extrudes into shallow crustal levels as a first step, followed by doming at a later stage. The so-called 'mountain building' process is restricted to the second stage. They attribute this Quaternary rapid uplift to rebound of the subducting Australian continental crust beneath Timor after it achieved positive buoyancy, due to break-off of the oceanic slab fringing the continental crust. In contrast, Tanimbar in the east has not yet been affected by later doming. A wide spectrum of processes, starting from extrusion of the high $\mathrm{P} / \mathrm{T}$ metamorphic rocks and ending with the later doming due to slab break-off can be observed in the Timor-Tanimbar region (see also Kadarusman, 2010).

The land barriers on the northern Wallacea is related with the docking of eastern arm of Halmahera and the emergence of North Maluku volcanic arc in Pliocene time. The land barriers in this northern Wallacea are eventually situated in the region where collisions are on going. Subduction in two directions in the Molucca Sea will bring its future disappearance and the Halmahera Arc as well, and there will only be one arc in the coming 2-3 million years (Hall, 2001).

\section{THE INDONESIAN THROUGHFLOW}

Within the Wallacea, a prominent oceanographic feature constitutes the well-known Indonesian Throughflow (ITF) which is the leakage of western tropical Pacific water into the southeastern tropical Indian Ocean through the
Indonesian seas (see e.g. Sprintall et al., 2004). The Indonesian Throughflow (ITF) which is the only remaining equatorial ocean gateway, is the flow of warm, relatively fresh waters into the southeast Indian Ocean from the Western Pacific Ocean via the series of passages between the islands of the Indonesian archipelago and Australia (Figure 2 ). As the world's only low-latitude interocean conduit, the ITF plays an integral role in the global thermohaline circulation and directly impacts the basin heat and freshwater budgets of both the Pacific and Indian Oceans (Sprintall and Liu, 2005).

The tectonic uplift and submergence of the thousands of islands and numerous passages that connect a series of large, deep basins within the Indonesian seas provide a tortuous and circuitous route for the ITF (Figure 2). These make the Indonesian seas function like a basin, and the Throughflow continues southerly and exits through the Lombok Strait, Ombai Strait and Timor Passage. During their transit, Pacific waters are converted into the distinctly fresh Indonesian Sea profile that is observed streaking across the South Indian Ocean within the zonal jet of the South Equatorial Current. The tendency for ocean boundary currents to pass through the westward-most available passage, and the sill depths of the various passages, largely define this pathway. Observations and models suggest that surface to upper thermocline waters of North Pacific origin flow through the relatively shallow and most westward Makassar Strait, while lower thermocline and deeper water masses of direct South Pacific origin arrive through the eastern Maluku and Halmahera Seas, with a dense water overflow at Lifamatola Passage (Sprintall et al., 2004).

The Pacific temperature and salinity stratification, as well as the local sea surface temperature, are modified by the strong air-sea fluxes, seasonal wind-induced upwelling, and large tidal forces within the Banda Sea (Ffield and Gordon, 1992). Furthermore, monitoring programs (Sprintall et al., 2004) suggest large differences in peak seasonal transport between the ITF inflow and outflow. The Banda Sea appears to act as a reservoir for warm surface waters, filling up and deepening its thermocline during the northwest monsoon, while 


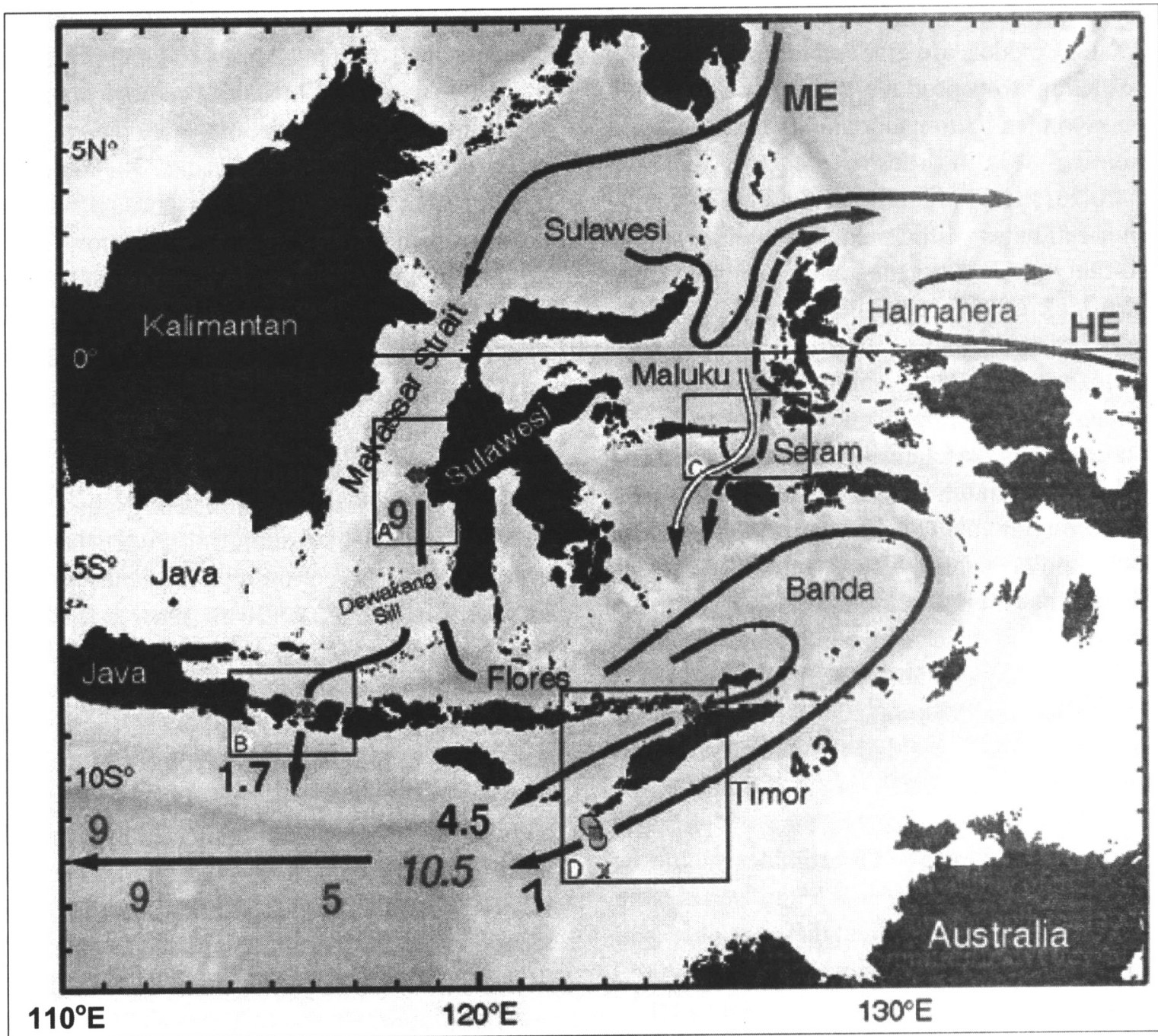

Figure 2. Schematic of Indonesian Throughflow pathways (black numbers represent previously determined transport in Sverdrups $(106 \mathrm{~m} 3 / \mathrm{s})$, and red numbers are total transports determined for the inflow and outflow passages (after Sprintall et al., 2004). ME is the Mindanao Eddy and HE is the Halmahera Eddy.

during the southeast monsoon, Ekman divergence (Sprintall and Liu, 2005) in the Banda Sea combined with lower sea level south of the Lesser Sunda Islands draw waters into the Indian Ocean.

The ITF is an important pathway for the transfer of climate signals and their anomalies around the world's oceans. The direction of the transport is strongly dependent on seasonal and annual climate although the total net annual transport is mostly southward from the Pacific Ocean into the Indian Ocean. It carries water from the western equatorial Pacific Ocean which has a higher temperature and lower salinity than the water in the Indian Ocean, and the Throughflow transports large amounts of relatively warm and fresh water to the Indian Ocean. When the
Indonesian Throughflow (through Lombok Strait and the Timor Passage) enters the Indian Ocean, it is advected towards Africa within the Indian South Equatorial Current. Here it eventually exits the Indian Ocean with the Agulhas Current around South Africa into the Atlantic Ocean (e.g. Gordon, 2005). Therefore, the Indonesian Throughflow transports a significant amount of Pacific Ocean heat into the southwest Indian Ocean, which is approximately $10,000 \mathrm{~km}$ away from the Lombok Strait (Wikipedia, 2012).

The magnitude and variability of the ITF were sources of major uncertainty for both the modeling and observational communities. They are the dominant sources of error in the basinwide heat and freshwater budgets for the Pacific and Indian 
Oceans (Wijffels et al., 2004). Though general circulation models are gradually improving, they were unable to reproduce the narrow passages and convoluted bottom topography of the internal Indonesian seas in order to adequately resolve the structure and variability of the ITF transport. Earlier estimates of the mean throughflow were wide-ranging $(2-22 \mathrm{~Sv})$ in part not only because of the lack of direct measurements, but also because of the real variation that can severely alias mean estimates if survey periods are not sufficiently long. Recent measurements reveal an unanticipated richness in the timescales of throughflow variability from intraseasonal (40-60 days) to interannual (Pacific El Niño and Indian Ocean dipole events). The different timescales are likely the result of remote forcing by both the Pacific and Indian Ocean winds, and the local monsoon forcing within the regional Indonesian seas (Wijffels and Meyers, 2004). Meanwhile the measurements suggest that the Makassar Strait inflow transport of $9.3 \mathrm{~Sv}$ is comparable to the transport sum of $10.5 \mathrm{~Sv}$ through the exit passages (Figure 2). These mean ITF estimates should be interpreted with caution, as the time series were made in different years and at different phases of the El Niño cycle. Later, Sprintall et al. (2009) determined the mean and variable transport of the Indonesian Throughflow (ITF) from fulldepth velocity measurements in the three major exit passages of Lombok Strait, Ombai Strait, and Timor Passage from January 2003 through December 2006. Collectively, these passages convey the full-depth transport and stratification profile of the ITF from the Pacific Ocean to the Indian Ocean. To first order, the seasonal cycle of transport in the thermocline $(\sim 100-150 \mathrm{~m})$ in all three exit straits is dominated by regional monsoon forcing, with maximum ITF during the southeast monsoon. During the northwest monsoon, the surface transport relaxes in Timor and weakly reverses in Ombai and Lombok, so the main core of the ITF is subsurface.

Little is known on the longer term evolution of the Indonesian Throughflow and its link to the global climate. Holbourn et al. (2011), for example, argued that the links between the Pacific and Indian Oceans via different passages between the oceans as sea level, as well as slowing of global thermohaline circulation during glacial intervals have changed during the last $140 \mathrm{ka}$. It is interesting also to note that climate and geological records suggest that ENSO variability may have existed on Earth as far back as the Eocene. The long-term development of the Indonesian Throughflow has been controlled by the geological history of the region but up to now there have been only a few studies of it (e.g. Kuhnt et al. 2004).

The western Pacific warm pool hosts the Indonesian throughflow, the network of currents through which surface and thermocline waters are transported from the western equatorial Pacific Ocean into the Indian Ocean. The high sea surface temperatures in the western Pacific warm pool fuel atmospheric convection and influence tropical climate. Linsley, et al. (2010) showed that from about 10,000 to 7,000 years ago, sea surface temperatures in the western sector of the western Pacific warm pool were about $0.5^{\circ} \mathrm{C}$ higher than during pre-industrial times. They also found out that about 9,500 years ago, when the South China and Indonesian seas were connected by rising sea level, surface waters in the Makassar Strait became relatively fresher, suggesting that the permanent reduction of surface salinity initiated the enhanced flow at lower, thermocline depths seen in the modern Indonesian throughflow. They indicated, however, the uniformly warm sea surface temperatures found upstream and downstream of the Indonesian throughflow indicate that the early Holocene warmth in this region was not directly related to reduce heat transport by the throughflow that may have resulted from surface freshening of the Makassar Strait. Instead, they proposed that the elevated temperatures were the result of a westward shift or expansion of the boundaries of the western Pacific warm pool.

\section{THE BIOGEOGRAPHY}

Areas of endemism within Wallacea are evaluated by Michaux (2010) by the distributional data and their relationship to each other and to the adjacent continental regions based on their molecular phylogenies from the literature. It was found out that the boundaries of these areas of endemism are in broad agreement with earlier works, but it was argued that the Tanimbar Islands are biologically part of south Maluku, rather than 
the Lesser Sundas, and that Timor (plus Savu, Roti, Wetar, Damar, and Babar) and the western Lesser Sundas form areas of endemism in their own right. Wallacean biogeographical units within Wallacea are identified by congruence between areas of endemism and geological history. Michaux (2010) concluded that although Wallacea as a whole is not a natural biogeographical region, neither is it completely artificial as it is formed from a complex of predominantly Australasian exotic fragments linked by geological processes within a complex collision zone. The Philippines are argued to be an integral part of Wallacea, as originally intended.

The presence of the Wallace's line has been widely used by much works to define the nature of exchange between the biotas through identifying major breaks in species composition. Knowledge of the marine biota of the region, however, is less than that of the terrestrial sphere (Benzie, 1998), and the concept of the region as a zone of overlap of two zoogeographic provinces (the Indian and the Pacific Oceans) has been considered of lesser significance. This is partly because the Indo-Pacific has generally been thought to be one major biogeographic region. Benzie (1998) mentioned that many taxa are found in both the Indian and Pacific Oceans, and the occurrence of widespread species in both oceans has led to the view that the floras and faunas of the two oceans are closely related. Explanations for the high diversity of marine species in SE Asia have concentrated on the idea that most species have evolved within the region. Sea-level changes over the last few million years are thought to have created isolated seas in which marine species have had a chance to diverge and speciate. This approach has tended to dominate thinking about the origin of marine biodiversity in SE Asia and the Indo-Pacific although a number of alternative views have been expressed with respect to the origin of species in the Pacific and Indian Oceans.

The Wallacea at the center of SE Asia has been considered a hot spot for marine speciation, and the likely source for much of the marine biota in the Pacific (see e.g. Benzie, 1998). Evidence from some genetic studies, however, were rare and not conclusive, and it has questioned ideas about the origin of marine biodiversity in the region. Most studies were focused on local areas or coastlines, or address specific questions relating to fisheries management. Furthermore, Benzie (1998) mentioned that some of the regional studies have provided evidence of cryptic species in groups where it might have been expected that the taxonomy was well-based. For example, genetic studies of the northern Australian fisheries thought to be based on Photololigo edulis and Photololigo chinensis were shown to consist of four cryptic species, none of which corresponded to $P$. edulis or $P$. chinensis from type localities in the China Sea. Cryptic species in taxa of coral which occur in the region (Montipora spp.) have been described in Australia. These suggest that many more cryptic and regionally defined taxa may occur in the region. Studies which examine genetic variation on a variety of geographical scales and/ or using a variety of genetic markers that might provide information pertinent to the evolution and biogeography of the SE Asian region are restricted to those on the butterfly fish Chaetodon spp., the starfish Acanthaster planci and Linckia laevigata, the milkfish Chanos chanos, and the giant clams Tridacna gigas, Tridacna derasa and Tridacna maxima (see Benzie, 1998 for more review).

Barber et al. (2000) argued, however, that as most coral reef organisms with a pelagic larval phase are presumed to be readily dispersed between distant populations, sea-surface current patterns should be crucial for predicting ecological and genetic connections among threatened reef populations. They investigated variations in the genetic structuring of populations of the mantis shrimp Haptosquilla pulchella taken from 11 reef systems in Indonesia, in which a series of 36 protected areas are presumed to be connected by strong ocean currents. They revealed that instead that there is a strong regional genetic differentiation that mirrors the separation of ocean basins during the Pleistocene low-sea-level stands, it indicates that ecological connections are rare across distances as short as $300-400 \mathrm{~km}$ and that biogeographic history also influences contemporary connectivity between reef ecosystems.

Similar to the populations of the pearl oyster, the sea urchin and related taxa, patterns of gene flow in giant clams do not parallel present-day ocean currents (Benzie, 1998). Clams may disperse by other present-day mechanisms such as surface 
drift, or have been dispersed by palaeocurrents at times of low sea level. However, both past and present mechanisms indicate movement of material from the Pacific to SE Asia. The high marine biodiversity in the region may result more from the accumulation of species evolved in the Pacific, relative to speciation within the SE Asian region, than has been believed traditionally. The mechanisms giving rise to marine biodiversity in the SE Asian region are not well-understood, therefore, and more work is urgently required to enable effective management of these resources.

\section{EARTH SYSTEM PROCESSES OF THE WALLACEA}

The unusual diversity within the Wallacea is eventually a vivid and living example of how a modern approach of Earth System Sciences may unravel a chain of complex multitemporal and multispatial geo-biodiversity processes, from a globe scale and six hundred millions of year deep mantle Whole Earth Tectonism or Plume Tectonics (Maruyama, 1994) processes down island scale and to millennium climatic and annual oceanographic cycles. The resulting Wallacea with its extremely rich endemism of terrestrial and marine organisms was a consequence of emergence and submergence of landmasses and formation of new basins and deepening or shallowing of the existing basins as well. The complex interplay between $\mathrm{Ce}$ nozoic rapid tectonic changes accompanying the northward movement of Australia as it converged with Asia, leading to the closure of the Indonesian Seaways in Early Miocene (e.g. Nishimura and Suparka, 1997; Hall et al., 2011), coupled with changes in the Indo-Pacific oceanographic regimes and global thermohaline flow, changes in the local climatic conditions, and the complex biotic migratory and evolutionary paths have all given way to the present peculiar biogeography of the Wallacea with its high numbers of endemic species, complex distribution patterns, and unusual variations in species richness.

The continuous closure of the Indonesian Seaways during the Cenozoic, which peaked up in the Pliocene, and proceeds until the present time was preceded by an open seaway and this remained fully open until before $25 \mathrm{Ma}$ (Figures. 4 a,b; see also Hall et al., 2011). Deep and cold current flows freely without barriers at the edge of the proto Sundaland. Small fraction of the upper and low density thermohaline of the paleo Indo-Pacific current may have flowed through the ancient Makassar Strait which had incipiently rifted in the south. The opening was argued to have corresponded with the uprising of a mantle wedge fragment beneath sub-continental lithosphere (see also Figure 3), most likely introduced into the crust and metamorphosed to spinel or garnet-bearing assemblage in collision zones in Central Sulawesi at the Late Eocene-Early Miocene (Sopaheluwakan, 2000; Kadarusman et al., 2002). By the onset of Miocene (Figure 4c, see also Hall et al., 2011; Kuhnt et al., 2004), the closure of the Indonesian Seaways was begun by the northward incoming splinters of Australian continental fragments forming the Bird's Head, Buru, Seram, Buton and the westward translation of proto Banggai-Sula Block by the ancient Sorong Fault; the East Arm of Sulawesi coming from the southern hemisphere and uprising of calc-alkaline volcanic arc of the North Arm of Sulawesi. These Early Miocene events may have coincided with the first restriction of the Indonesian Seaways, and termination of deepwater flow, major perturbations in the global climate system including rapid warming in the Late Oligocene followed by a brief glaciation pulse (Zachos et al. 2001). Opening of the Southern Makassar Strait became much wider than before, but remained shallow and allowing the warm surface water to flow along the strait and induced suitable carbonate depositional environment during Oligocene - Early Miocene across South Sulawesi and South Kalimantan (see e.g. Moss and Wilson, 1998).

Further closure of the Indonesian Seaways reached their initial spatial revolutionary stage during the Late Miocene (Figure 4d), during which the Banggai-Sula microcontinental block has stopped rafting to the west and docked onto the East Arm of Sulawesi and the Lesser Sunda Islands volcanic arc was active and younging eastward (e.g. Sopaheluwakan, 1990). The Strait of Makassar deeply opened in the north, and attempted short-lived extension occurred in the Bone Strait and beneath the narrow passage north of Timor promontory. Deep and cold Pacific current became more restricted and was only possible to flow through the narrow passage between the 
northern tip of Australian Continental mass and the docked Banggai-Sula block and the newly upraised islands of Banda volcanic arc. Incipient blockage of the ancient ITF by the Lesser Sunda Islands has occurred during this period. The Buru-Seram were still on their northward translation, allowing the Pacific current to flow through the narrow passage between the Bird's Head and the Banggai-Sula Block and further southwestward through the ocean channel between Timor promontory and the Lesser Sunda volcanic arc.

The final major perturbation of the Wallacea window was in Pliocene, during which significant restriction of the throughflow took place in the region (Figure 4e). The only deep and narrow ocean Indo-Pacific passage were closed by the incoming Bird's Head of Papua (Cane and Molnar, 2001), final rotation of Buru-Seram microcontinent (Linthout et al., 1997) and the shortening of proto Ombai Strait, making the gap between Timor and Wetar closer (e.g. Sopaheluwakan, 1990). Halmahera was a much smaller island 3-5 Myr ago than it is today. Much, if not all, of Halmahera, which currently plays a major role in preventing water from the southern Pacific from joining the Indonesian throughflow, apparently has emerged since 5 Myr ago (Cane and Molnar, 2001). The warm saline South Pacific water gradually reduced its flow and the colder North Pacific water became the major influx to flow through the main passage of the Makassar Strait.

The tectonic history of the Indonesian Seaways ultimately controlled the long-term evolution of the throughflow (Kuhnt et al., 2004). During the Pliocene, changes in the position and geometry of the inflow passages (Mindanao Passage to the North and Halmahera Passage to the south) in relation to the tropical Pacific front significantly modified the climatic role of the tropical Indian and Pacific Oceans, resulting in reduced atmospheric heat transport from the tropics to high latitudes. Cane and Molnar (2001) proposed that cooler surface water in the Indian Ocean resulted in increased aridity over eastern Africa. Decreased heat transport out of the tropics may have also stimulated global cooling, resulting in the formation of ice sheets.

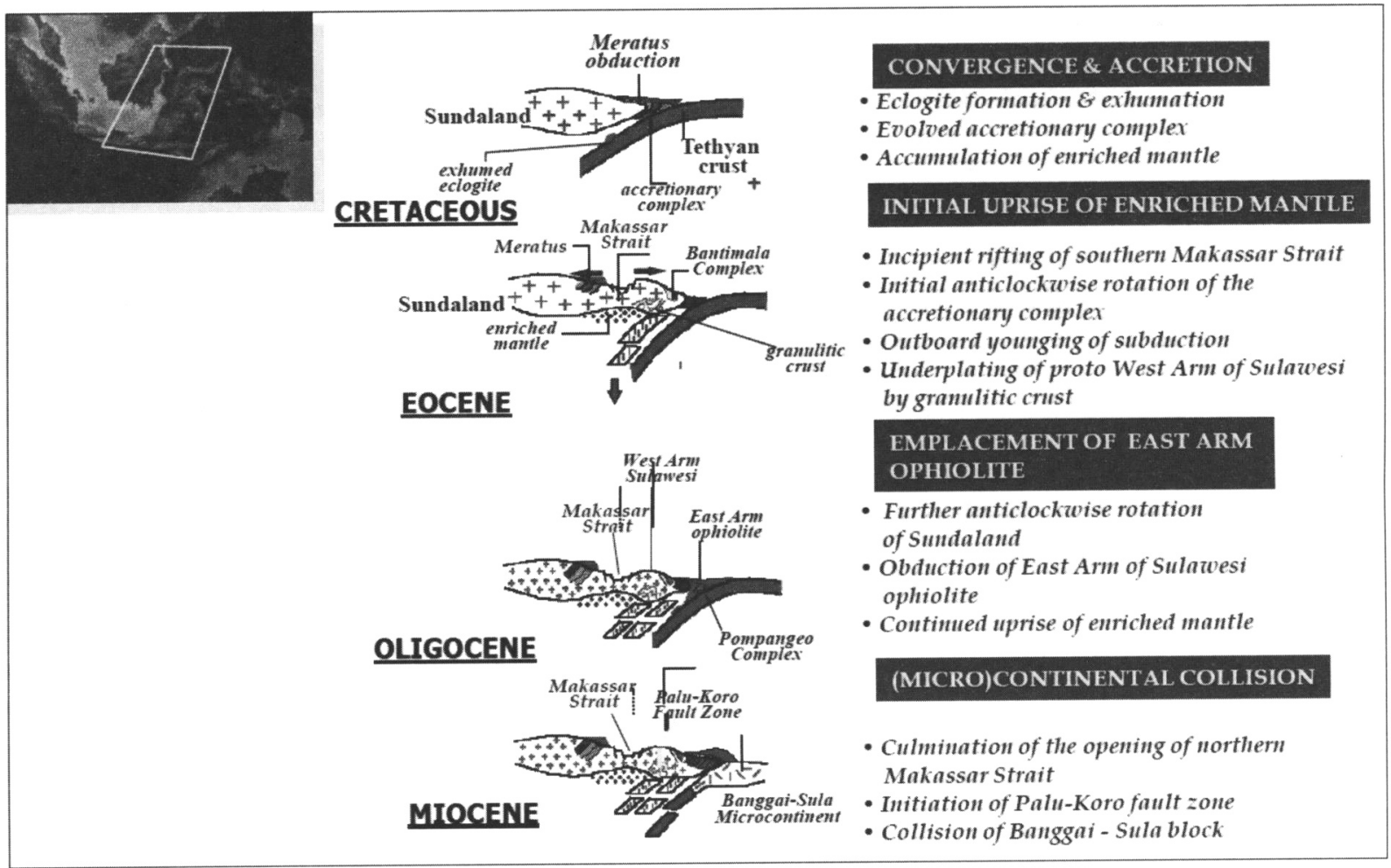

Figure 3. Late Mesozoic - Early Cenozoic evolution of the Southeast Sundaland Margin, showing the evolutionary paths of the Strait of Makassar (Sopaheluwakan, 2000). The Strait of Makassar was formed as a result of Eocene incipient rifting along with the southeastward outboard younging of subduction and the rise of enriched mantle. The rifting was aborted due to the docking of Banggai-Sula microcontinental blocks. 


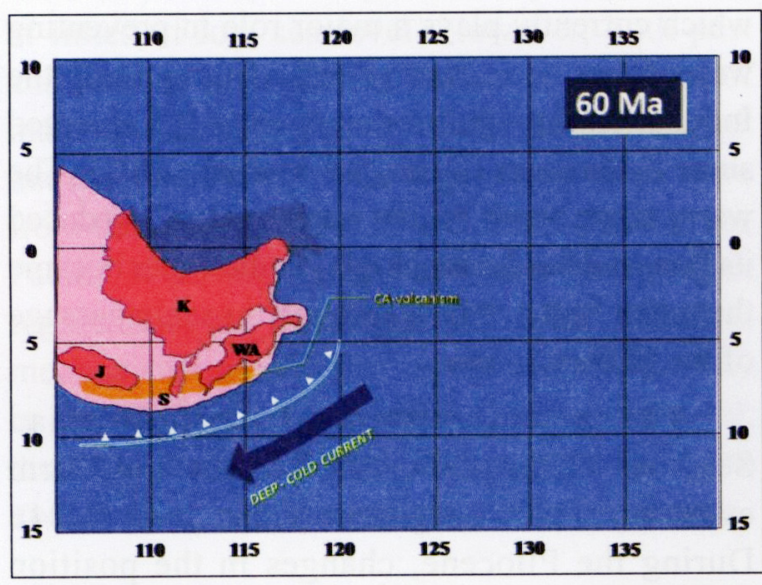

Figure 4a. Subduction at the southeastern tip of the Sundaland and the free flowing deep and cold Tethyan ocean current (dark blue arrow) $\mathrm{K}=$ Kalimantan, $\mathrm{J}=$ Java, $\mathrm{S}=$ Sumba, WA $=$ West Arm of Sulawesi, orange belt $=$ calc-alkaline volcanism .

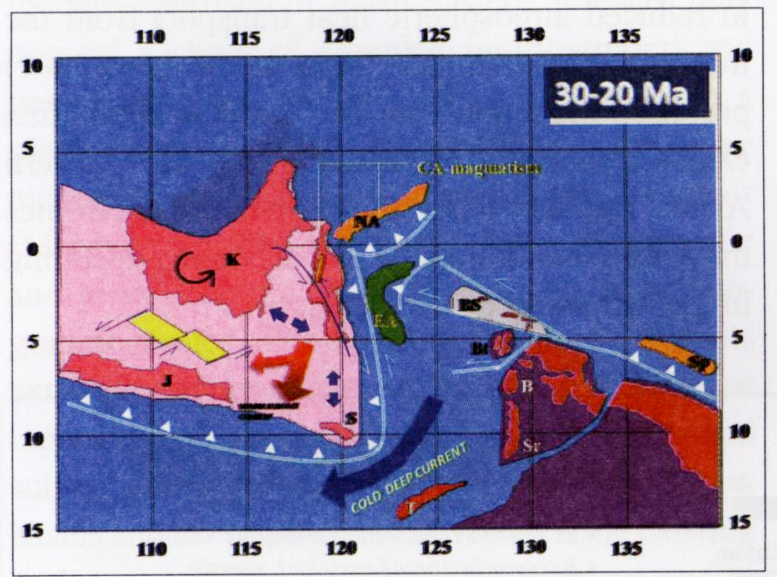

Figure 4c. Initial closure of the Indonesian Seaways in the mid Tertiary incipient collisional tectonism within the Wallacea window. South Makassar Strait was fully opened, Sumba migrated southward to its present position, the calc-alkaline magmatism was active in the proto North Arm of Sulawesi. East Arm oceanic fragment was incoming, chased by the Banggai - Sula Australian fragments sliced along the ancient Sorong Fault Zone. Timor promontory moved northward, while the Buru-Seram-Buton fragments were not translated far from the Papuan continent. Deep and cold IndoPacific ocean current (dark blue arrow) passed through the wide channel formed by the incoming Australian continent and the Southeast Eurasian continent. Warm surface current (red arrow) flows along the Makassar Strait. $\mathrm{K}=$ Kalimantan, $\mathrm{J}=$ Java, $\mathrm{S}=$ Sumba, NA = North Arm of Sulawesi, EA = East Arm of Sulawesi, T $=$ Timor, $\mathrm{BS}=$ Banggai - Sula, $\mathrm{Bt}=$ Buton, $\mathrm{B}=$ Buru, $\mathrm{Sr}=$ Seram, $\mathrm{Sp}=$ Sepik.

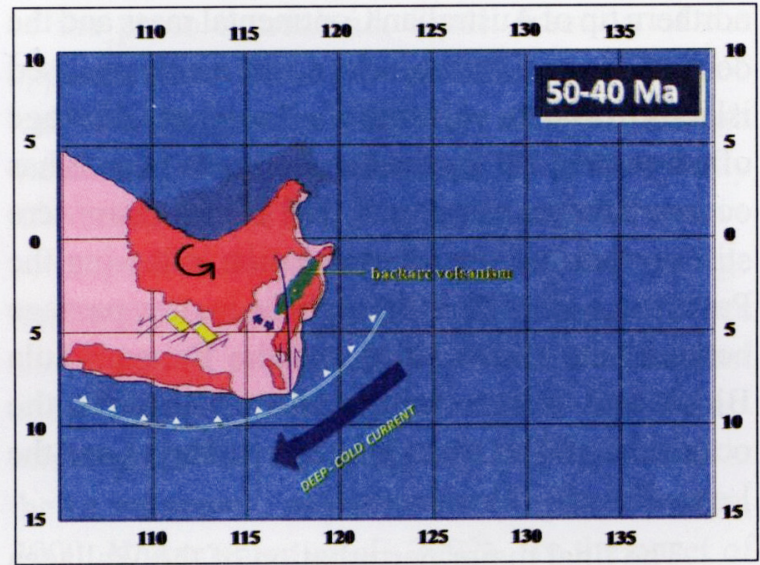

Figure 4b. Early Tertiary initial opening of the proto Makassar Strait due to backarc extension and along with the anticlockwise rotation of the SE tip of the Sundaland margin. The deep and cold Tethyan Ocean current flows freely with no barrier.

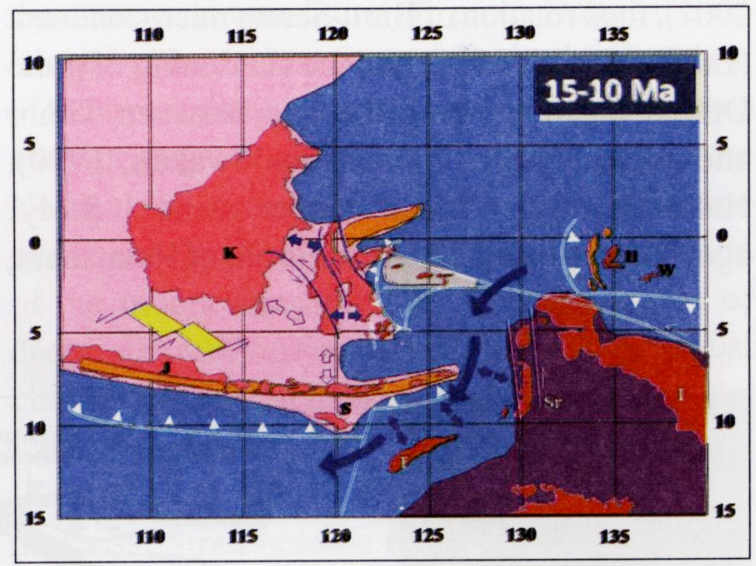

Figure 4d. Narrowing passages of the Indonesian Seaways along with opening of the North Makassar Strait, attempted opening of the Bone Bay and short lived extension north of Timor promontory. Translatory placement of Buton and Banggai-Sula microcontinents were in their final stage. Sumba arrived in its final position and eastward younging of the Lesser Sunda island arc was in progress, causing the initial blockage of the Neogene warm north Pacific ocean current flowing through the proto Makassar Strait. Buru and Seram were translated northward. Halmahera arc was in incipient stage and the east arm Halmahera oceanic crust moved westward approaching the Halmahera arc. Deep and cold equatorial Pacific current flowed restrictedly through the narrow passage between the Australian continent and the newly emerged islands. 


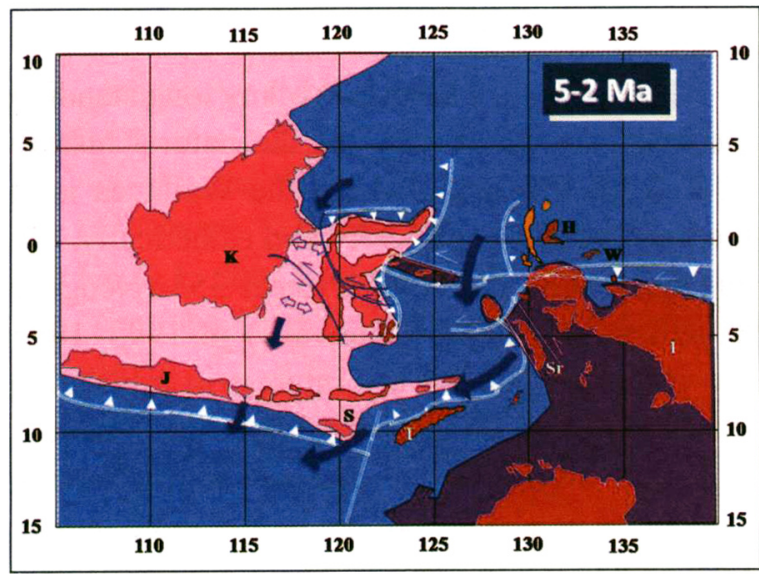

Figure 4e. Pliocene paleogeography of the Wallacea window, showing the final stage of the major perturbation of the plate reconstruction and significant restriction of the throughflow in the region. Buru-Seram started to rotate anticlockwise, Banggai-Sula was fully docked, deep narrow ocean passage in north of Timor was shortened and nearly closed, along with the uplift of Timor-Tanimbar islands. The Makassar Strait was already in their equilibrium as in today. There might have been a switch on the thermohaline flow, from warm saline South Pacific Water to colder North Pacific water, leading to the present flow through the main passage of the Makassar Strait.. Halmahera arc and its East Arm were smaller and about to collide to produce the future barrier of the southern Mindanao Passage.

\section{CONCLUSION}

Interdisciplinary approach of Earth System Science-which seeks interaction between the atmosphere, hydrosphere, lithosphere (geosphere), biosphere, and heliosphere-has helped in unraveling the complexities of tectonic history and its bearing to the (paleo)ceanographic regimes, the (paleo)climatic responses and the unusual patterns of the resulting biogeography of the Wallacea. It involves multispatial changes in different temporal cycles, from the deep South Pacific mantle plume processes as the ultimate major driver of 600 millions year cycle through tens of millions year dynamics of the plate tectonics, along with divergence and speciation of marine and terrestrial organisms, to millennia long climatic processes down to annual oceanographic cycles.

The history of the Wallacea corresponds well with the closure of the Indonesian Seaways, which is the only critical zonal tropical ocean passage remained on Earth. It strongly influenced global

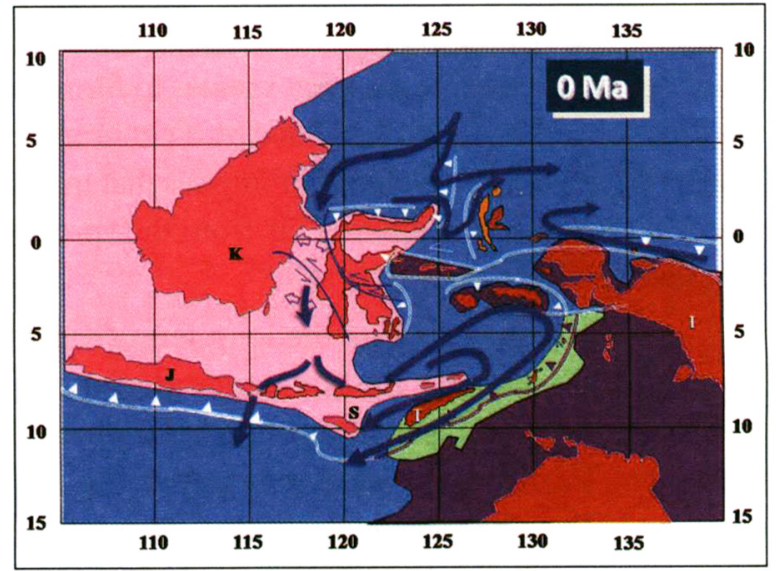

Figure 4f. Present configuration of the ITF with all the main island barriers are emplaced (Halmahera passage was formed in the south of the Mindanao Passage, and blockage of the islands around the Banda Arcs in the middle and the south as well). Timor - Tanimbar stretch continued to be uplifted to accommodate most of the shortening due to the collision of Australia and the Banda Arcs. The ITF configuration is referred to in Figure 2 as well as in the text.

ocean circulation in the Neogene and its closure was associated with dramatic changes in the global thermohaline circulation. The Indonesian Seaways is still open for surface and intermediate water circulation. Thus, the tectonic and oceanographic history of the SE Asia-Australia collision zone is of considerable importance for understanding regional and global climate change during the Neogene. The resulting emergence and submergence of landmasses, and the formation of new basins and deepening or shallowing of the pre-existing basins have then formed the extraordinarily rich marine and terrestrial organisms in the Wallacea.

The great coincidence between the plate tectonic history of the Wallacea and the ensuing paleogeographic, paleoclimatic and paleoenvironmental responses are well demonstrated, and to a large extent the terrestrial biogeographic pattern as well. When it comes to the high diversity of marine organism and their distribution in the Wallacea, however, different views occur between the idea that most species have diverge 
and speciate within the region against those who provided an alternative idea that species to form by divergence of populations divided by a geographic barrier (Benzie, 1998). The latter implies that many species must have originated far from the (proto) Wallacea as the center of origin.

It is interesting to note the long term (Kuhnt et al., 2004) and the long distance (Cane and Molnar, 2001) impacts of the closure of Indonesian Seaways. The Pliocene plate reorganization and changes in the position and geometry of the inflow passages in relation to the tropical Pacific front significantly modified the climatic role of the tropical Indian and Pacific Oceans. This resulted in reduced atmospheric heat transport from the tropics to high latitudes. The aridification of Africa by Pliocene followed by the onset of Pleistocene glaciation in the high latitude follows the complete closure of the Seaways (Cane and Molnar, 2001) is of particular interest, since it induced global climate change around 3-4 Myr ago and was thought to have influenced the evolution of hominids in Africa.

The timing and mode of the closure of Indonesia Seaways are thought to be of critical importance to be studied further in much greater detail. The mechanism and timing of the full closure of the Indonesian Seaways need to be examined in somewhat greater detail in several critical passages like: (1) the final emplacement of the land barriers around the Bird's Head of Papua, Buru-Seram rotated block and the Halmahera passage; (2) shortening of the Ombai Strait and Timor Passage; (3) final opening and equilibrium stage of the Makassar Strait which became the major conduit for the throughflow from the North Pacific when the warm South Pacific water was prevented to flow through the narrow channel around the Bird's Head during the Pliocene. All of these key studies are to address the issues of: (1) when exactly was the change of paleoceanographic regimes during the Plio-Pleistocene time, whereby the warm South Pacific water flow had switched to the colder North Pacific water to flow through the Makasssar Strait; (2) how was the paleoclimatic change responded to this tectonic change; and (3) is there any significant change in the distribution pattern of the marine and terrestrial organisms.

\section{ACKNOWLEDGEMENT}

This paper is a reflection of my long standing fascination to the beauty of the natural history of Eastern Indonesia where the Wallacea is at the heart of it, scientifically and esthetically. My encounter with the IGCP Project 355 (Neogene Evolution of Pacific Gateways) in 1993-1995 has initially widened my interest in translating the tectonic evolution of the Indonesian Seaways and their impact to the paleoceanographic and paleoclimatic changes in the Indo-Pacific region. I developed my interest on oceanography when I Chaired the Indonesian National Commission of UNESCO's Intergovernmental Oceanographic Commission in 2001-2005, during which I am indebted to Dr. Ilahude Gani who introduced me with some fundamentals on oceanography. Colleagues at Research Center for Oceanography LIPI are thanked for their support. Biogeography was a field of intriguing interest when I participated in the Biogeography 2000 Seminar held in Leiden in 2000. Particular attention to the Wallacea was then developed when LIPI and the Indonesian Academy of Sciences jointly organized the International Conference on Alfred Russel Wallace and the Wallacea in 2008 in Makassar. This paper is a recollection of that conference.

\section{REFERENCES}

Ballantyne, P.D., R. Hall., J. Malpas, E.M. Moores, A. Panayiotou, and C. Xenophontos (eds.). 1990. The Halmahera Ophiolite, Indonesia: an Early Tertiary fore-arc. In Ophiolites: Oceanic Crustal Analogues. Geological Survey of Cyprus, p. 461-475.

Barber, P.H., S.R. Palumbi, M.V. Erdmann, and M.K. Moosa. 2000. Nature, 406: 692-693.

Bemmelen, R. W. van (Reinout Willem van). 1949. The Geology of Indonesia. The Hague: Govt. Printing Office, 2 volumes.

Benzie, J.A.H. 1998. Genetic Structure of Marine Organisms and SE Asian Biogeography. In: Hall, R. and J.D. Holloway (eds.) Biogeography and Geological Evolution of SE Asia Backhuys. Leiden, p. 197-209.

Cane, M.A. and P. Molnar. 2001. Closing of the Indonesian Seaway as a Precursor to East African Aridification around 3-4 million years ago. Nature, 411: 157-162. 
Darman, H. and H. Sidi (eds.). 2000. An Outline of the Geology of Indonesia. Indonesian Geologists Association publication.

Ffield, A.. and A.L. Gordon. 1992. Vertical Mixing in the Indonesian Thermocline. Journ.Phys. Oceanogr., (22): 184-195.

Gordon, A.L. 2005. Oceanography of the Indonesian Seas and Their Throughflows". Oceanography, 18(4): 14-7.

Gordon, A.L. and R.D. Susanto. 2001. Banda Sea Surface Layer Divergence Ocean Dynamics, 52(1): 2-10.

Hall, R. 1998. The Plate Tectonics of Cenozoic SE Asia and the Distribution of Land and Sea. In: Hall, R. and J.D. Holloway (eds), Biogeography and Geological Evolution of SE Asia Backhuys Publishers, Leiden, p. 99-124.

Hall, R. 2001. Cenozoic Reconstructions of SE Asia and The SW Pacific: Changing Patterns of Land and Sea. In: Metcalfe, I., J.M.B. Smith, M. Morwood and I.D. Davidson (eds.) Faunal and Floral Migrations and Evolution in SE AsiaAustralasia. A.A. Balkema (Swets \& Zeitlinger Publishers) Lisse, p. 35-56.

Hall, R. 2002. Cenozoic Geological and Plate Tectonic Evolution of SE Asia and the SW Pacific: Computer-Based Reconstructions, Model and Animations. Journ. Asian Earth Sciences, (20): 353-431.

Hall, R. M.A. Cottam, M.E.J. Wilson. 2011. The SE Asian Gateway: History and Tectonics of the Australia-Asia Collision, Geol. Soc. London, Spec. Publ., 355: 1-6. doi: 10.1144/SP355.1.

Holbourn, A., Kuhnt W. and J. Xu. 2011. Indonesian Throughflow Variability during the Last $140 \mathrm{ka}$; the Timor Sea Outflow. In: The SE Asian Gateway; History and Tectonics of the Australia-Asia collision, Geol. Soc. London. Spec. Publ. 355: 283-303

Holloway, J.D. and R. Hall. 1998. SE Asian Geology and Biogeography. In: Hall, R. and Holloway J. D. (eds.) Biogeography and Geological Evolution of SE Asia. Amsterdam: Backhuys Publishers, p. 1-23.

Kadarusman, A., Jan Sopaheluwakan, T. van Leeuwen. 2002. Eclogite, Peridotite, Granulite and Associated High-Grade Rocks from Palu-Koro Region, Central Sulawesi, Indonesia: An Example for Mantle and Crust Interactions in Young Orogenic Belt, American Geophysical Union, Fall Meeting, abstract T61A-1230.
Kadarusman, A., S.Maruyama, Y. Kaneko, T. Ota, A. Ishikawa, J. Sopaheluwakan, and S. Omori. 2010. World's Youngest Blueschist Belt from Leti Island in the Non-Volcanic Banda Outer Arc of Eastern Indonesia. Gondwana Research, (18) 1: 189-204.

Kaneko, Y., S. Maruyama, A. Kadarusman, T. Ota, M. Ishikawa, T. Tsujimori, A. Ishikawa, and K. Okamoto. 2007. On-Going Orogeny in the Outer-Arc of the Timor-Tanimbar Region, Eastern Indonesia. Gondwana Research, 11: 218-233.

Katili, J. A. 1978. Past and Present Geotectonic Position of Sulawesi, Indonesia. Tectonophysics, 45 (4): 289-322.

Kennet, J.P., G. Keller, and M.S. Srinivasan. 1985. Miocene Planktonic Foraminiferal Biogeography and Paleogeograpic Development of the Indo-Pacific Region. In: The Miocene Ocean: Paleogeography and Biogeography. Geological Society of America Memoir, 163: 197-236.

Kuhnt, W, A. Holbourn, R. Hall,, M. Zuvela, and R. Kase. 2004. Neogene History of the Indonesian Throughflow. Continent-Ocean Interactions Within East Asian Marginal Seas, Geophysical Monograph Series, vol.149, American Geophysical Union, Geophysical Monograph, 299-320.

Linthout, K., H. Helmers, and J. Sopaheluwakan. 1997. Late Miocene Obduction and Microplate Migration around the Southern Banda Sea and the Closure of the Indonesian Seaway. Tectonophysics, 281: 17-30.

Linsley, K.B., Y. Rosenthal, and D.W. Oppo. 2010. Holocene Evolution of the Indonesian throughFlow and the Western Pacific Warm Pool. Nature Geoscience 3: 578-583.

Lus, W.Y., I. McDougall, and H.L. Davies. 2004. Age of the Metamorphic Sole of the Papuan Ultramafic Belt ophiolite, Papua New Guinea. Tectonophysics, 392 (1-4): 85-101.

Maruyama, S. 1994. Plume Tectonics. Journal of the Geological Society of Japan 100: 24-49.

Maruyama, S., M. Kumazawa, and S. Kawakami. 1994. Towards a New Paradigm on the Earth's Dynamics, Journ. Geol. Soc. Japan, (100): 1-3.

Michaux, B. 2010. Biogeology of Wallacea: Geotectonic Models, Areas of Endemism, and Natural Biogeographical Units. Biol. Journ. of the Linnean Society, 101 (1): 193-212.

Moss, S.J. and M.E.J. Wilson. 1998. Biogeographic Implications of the Tertiary Paleogeographic Evolution of Sulawesi and Borneo. In: Hall, R. and J.D. Holloway (eds.) Biogeography and Geological Evolution of SE Asia. Amsterdam: Backhuys Publishers, p. 133-163. 
Nishimura, S. and S. Suparka. 1997. Tectonic Approach to the Neogene Evolution of PacificIndian Ocean seaways. In: Neogene Evolution of the Pacific: Tectonics of Gateways and Associated Responses, Tectonophysics, 281 (1-2): $1-16$.

Parkinson, C.D. 1998. An Outline of the Petrology, Structure and Age of the Pompangeo Schist Complex of central Sulawesi, Indonesia. Island Arc, 7 (1-2): 231-245.

Parkinson, C.D., K. Miyazaki, K. Wakita, A.J. Barber, D.A. Carswell. 1998. An Overview and Tectonic Synthesis of the Pre-Tertiary Very-HighPressure Metamorphic and Associated Rocks of Java, Sulawesi and Kalimantan, Indonesia. Island Arc, 7 (1-2): 184-200.

Sopaheluwakan, J. 1990. Ophiolite Obduction in the Mutis Complex, Timor, Eastern Indonesia: An Example of Inverted, Isobaric, Medium-High Pressure Metamorphism. Ph.D. Thesis, Vrije Universiteit, Amsterdam, the Netherlands.

Sopaheluwakan, J. 1995. Cenozoic Tectonic Evolution of Indonesian Seaways. Oji Seminar, IGCP-35, Kyoto, Oct. 1995.

Sopaheluwakan, J. 2000. Cenozoic Tectonic Evolution of Indonesian Seaways, Biogeography of Southeast Asia 2000 Congress: Organisms and Orogenesis (abstract), Leiden.

Sopaheluwakan, J. 2007. Geodinamika Indonesia dan Keberlangsungan Hidup Manusia: Dari Ilmu Kebumian ke Ilmu-Ilmu Sistem Kebumian. Geol. Res. Dev. Centre, Bandung, Spec. Publ. 33 (1): 1-27.
Spakman, W. and R. Hall. 2010. Surface Deformation and Slab-Mantle Interaction during Banda Arc Subduction Rollback. Nature Geoscience, doi: 10.1038/NGEO917, p 1-5.

Sprintall, J., S. Wijffels, A.L. Gordon, A. Ffield, R. Molcard, R.D.S.I. Soesilo, J. Sopaheluwakan, Y. Surachman, and H. M. van Aken. 2004. Eos, 85 (39): 369-376.

Sprintall, J.and W. T. Liu. 2005. Ekman Mass and Heat Transport in the Indonesian Seas. Oceanography: 18 (4): $88-97$.

Sprintall, J., S.E. Wijffels, R. Molcard, and I. Jaya. 2009. Direct Estimates of the Indonesian Throughflow Entering the Indian Ocean: 2004-2006. Journ. Geophys. Res., 114: 1-19. C07001, doi:10.1029/2008JC005257.

Villeneuve, M., W. Gunawan, J.J. Cornee, and O. Vidal. 2002. Geology of the Central Sulawesi Belt (Eastern Indonesia): Constraints for Geodynamic Models. Int'l. Journal Earth Sci., 91(3): 524-537.

Umbgrove, J.H.F. 1942. The Pulse of the Earth. The Hague. NL: Nyhoff.

Wijffels, S., J. Toole, and R. Davis. 2004. Revisiting the South Pacific Subtropical Circulation: A Synthesis of World Ocean Circulation Experiment Observations along $32^{\circ} \mathrm{S}$. Journ. Geophys. Res.,106: 19481-19514.

Wijffels, S. and G.A. Meyers. 2004. An Intersection of Oceanic Wave Guides: Variability in the Indonesian Throughflow Region. Journ. Phys. Oceanogr., 34, 1232-1253.

Zachos J., M. Pagani, L. Sloan, E. Thomas, and K. Billups. 2001. Trends, Rhythms and Aberrations in Global Climate 65 Ma to Present. Science 292: 686-693. 